\title{
The Role of Government in the United States in Addressing Natural Catastrophes and Environmental Exposures
}

\author{
by Franklin W. Nutter*
}

Insurers doing business in the United States today are faced with extraordinary potential losses from natural catastrophes and skyrocketing claims for the clean-up of hazardous waste sites pursuant to the "Superfund" law. In both cases, U.S. insurers are turning to government as a partner in addressing these exposures.

\section{Natural catastrophes}

While the number of natural catastrophes worldwide has increased rather dramatically in recent years, in the last 20 years the United States has experienced little change on a year-to-year basis in the number of such catastrophes. Using their criteria, Swiss $\mathbf{R e}$ reports that in the period 1970 to 1981, there were 132 catastrophes worldwide, and in the period 1982 to 1992, 226 such catastrophes - an increase of 94 percent over the prior 10 year-period. With regard to the United States, however, the number of catastrophes ${ }^{1}$ reported were as follows:

$1949-1959$

88

$$
1960-1969
$$

$$
\text { 1970-1979 }
$$$$
327
$$

$$
1980-1989
$$$$
313
$$

$1990-1993$

124

Thus, the occurrence of natural catastrophes has been rather stable in the United States in the last 20 years, although there was a fairly significant increase from the preceding 20-year period. Natural catastrophes in this context include hurricanes, earthquakes, wild fires and, in a few cases, man-made occurrences (e.g., petro-chemical explosion).

\subsection{Severity of catastrophes}

While the frequency of natural catastrophes may be startling to some, it is the magnitude of these catastrophes in the United States and the size of the insured loss that is far more notable. Prior to mid-1988, the insurance industry worldwide had never experienced insured losses from a single event which exceeded $\$ 1$ billion. Since mid-1988, the industry holm.

* Text presented at The General Assembly of the Geneva Association, June 10, 1994, in Stock-

${ }^{1}$ The number of U.S. catastrophes is based on the criteria of the Property Claims Services. 
worldwide has experienced 14 such events. The Property Claims Services report that of the 20 largest insured catastrophes in the United States, 16 have occurred since 1989;12 of those 20 involved a combination of wind (hurricane) and water (flooding). Exhibit 1 lists each of those natural catastrophes together with their dates, states affected and the insured loss.

Looking at the U.S. insurance industry's historical catastrophe losses from 1949 to 1993, as set forth in Exhibit 2, one can see that the number of natural catastrophes has increased since the 1940's and 1950's but has remained relatively stable in the 1970's, 1980's and 1990's. The insured loss, however, has risen dramatically, peaking in 1992 at nearly $\$ 23$ billion in claim payments as a direct result of natural catastrophes alone. Over more than four decades, 45 percent of all catastrophes related insured claims have been paid since 1990.

\subsection{Trends affecting insured losses}

In recent years, scientists and researchers outside our industry have dramatically improved their ability to monitor changes in climate and have advanced various theories for these changes, including global warming, El Nino, changes in dry and rainy seasons in West Africa, volcanic activity, and acid rain. These meteorological developments, or a combination of them, appear to be having an effect on insured loss experience. It is also clear that two significant trends have deeply affected the insurance industry's loss experience due to changes in weather conditions.

The first of these trends is growth in insured exposures as a result of population shifts. Census data shows that 50 percent of the U.S. mainland population lives within 50 miles of a coast ; 44 percent of our population lives in coastal counties where the population density is four times the national average. By the year 2010, the U.S. coastal population is estimated to be 127 million people. This is based on analyses which suggest that of the 20 states that can expect to experience population growth by the year 2010,17 are coastal states. This trend includes significant development on barrier islands, as our population has been attracted to coastal waterways and shorelines. This shift in our population to high risk coastal areas is exacerbated by the ballooning effect that tourism and vacation homes have on the population exposed to coastal natural catastrophes such as hurricanes, flooding, and windstorms. It is reported that it is not uncommon for popular coastal communities to increase their "population" by a factor of 10 during warm weather seasons, including seasons during which hurricane activity is most prominent: late summer and early fall. With these population shifts come higher exposure to loss of life and property to both sudden and gradual forces of nature.

The second major trend affecting the insurance industry is growth in exposure due to increases in insured values in high risk areas. Estimates are that the insurance industry's total exposure in coastal communities in 1992 is slightly in excess of $\$ 8$ trillion in insured value, an increase from $\$ 1.13$ trillion in 1980 . The loss potential due to natural weather forces in extraordinary.

Other causes contributing to increased insured damages include broadened policy coverages (e.g., extended living expenses) and a greater propensity to insure. 


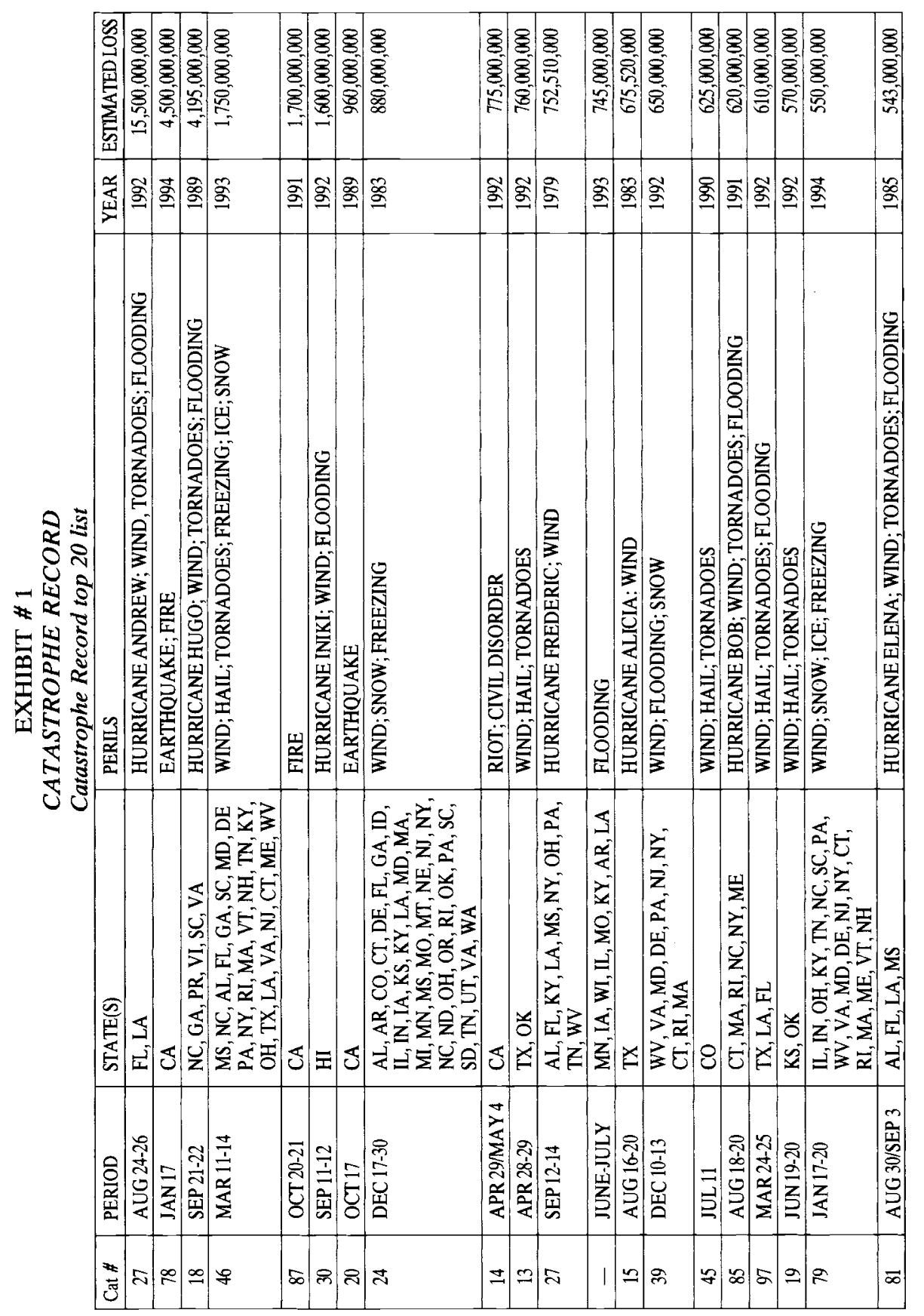

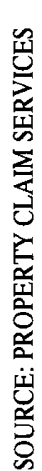


EXHIBIT \# 2

Catastrophes Losses, 1949-93

1949

\# OF CATS

1950

1951

1952

1953

1954

1955

1956

1957

1958

1959

1960

1961

1962

1963

1964

1965

1966

1967

1968

1969

1970

1971

1972

1973

1974

1975

1976

1977

1978

1979

1980

1981

1982

1983

1984

1985

1986

1987

1988

1989

1990

1991

1992

1993

4

9

4

6

15

10

9

8

11

6

6

9

13

17

8

19

12

15

28

19

19

18

32

30

36

26

31

27

40

41

54

51

33

33

33

26

34

26

24

32

34

32

36

36

36
(\$Millions)

22.3

222.3

16.5

17.8

87.7

293.4

91.4

56.8

73.6

20.5

47.2

130.0

169.3

192.3

32.7

225.2

851.4

106.8

185.0

127.1

253.2

413.3

128.6

211.3

358.6

656.5

501.6

273.1

366.2

652.8

$1,684.6$

$1,177.0$

714.2

$1,528.4$

$2,254.8$

$1,548.3$

$2,783.3$

871.5

946.0

$1,409.0$

$7,642.0$

$2,825.0$

$4,223.0$

$22,970.0$

$5,620.0$

Source: Property Claims Service Div., American Insurance Services Group Inc.; A. M. Best Co. 
Exhibit \#3

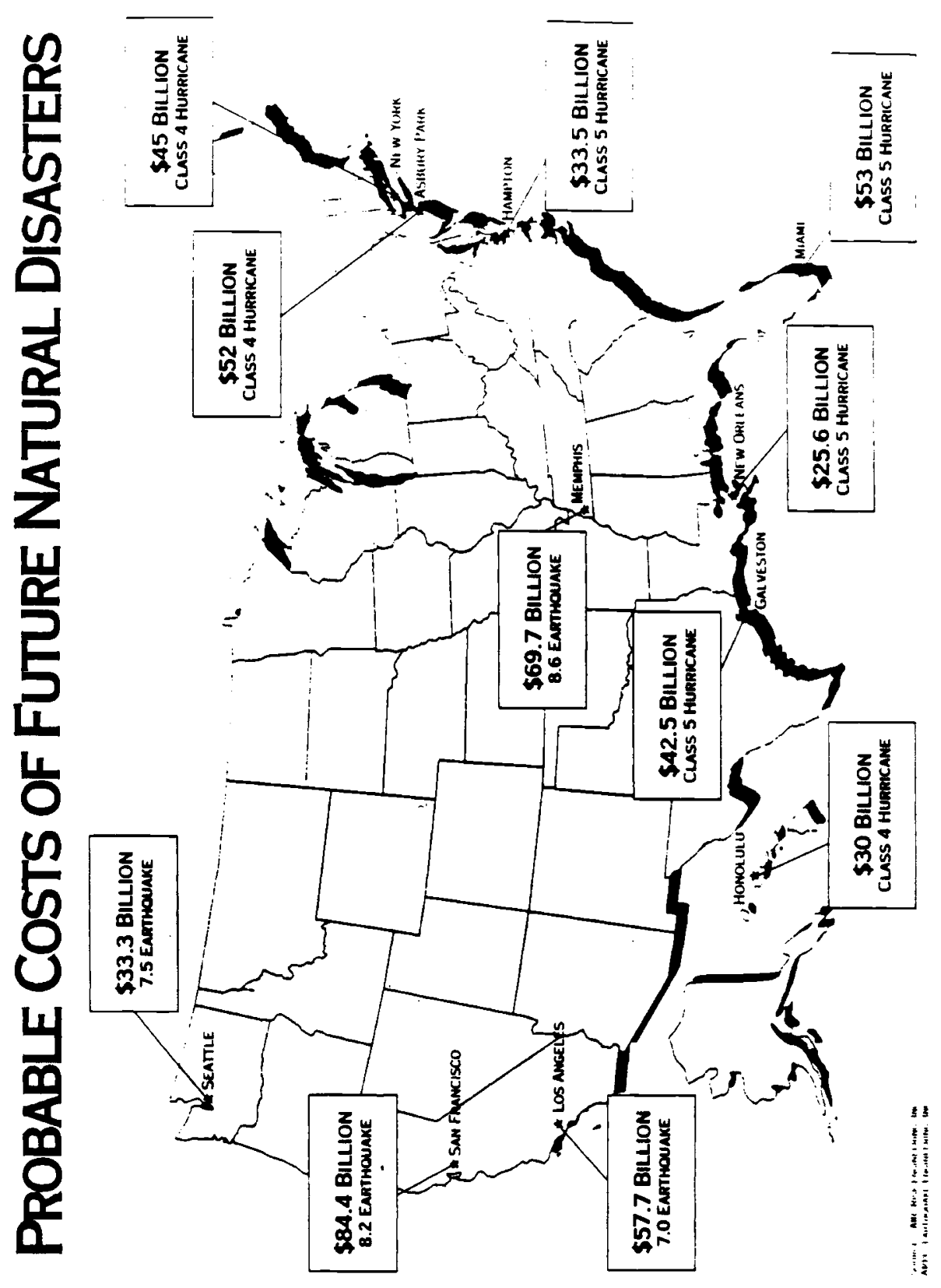




\subsection{Probable maximum loss}

Yet it is not just recent loss experience for the industry that has caused it to rethink its relationship to government. That development is probably more the result of an analysis of potential future losses.

Our industry has had the benefit in recent years of dramatic improvements in its ability to assess its exposure to natural catastrophes, both earthquake and hurricane, through computer models, using historical experience to calculate storm and seismic probability and loss potential. The potential insured losses from these events is staggering. Exhibit 3 reflects estimates of insured losses, including property, business interruption, workers compensation and other commercial losses as a result of various hurricane or earthquake scenarios. It shows that a class 5 hurricane striking New Orleans would be estimated at $\$ 25.6$ billion in insured loss; Galveston, Texas - $\$ 42.5$ billion; Miami $-\$ 53$ billion; Hampton, Virginia - $\$ 33.5$ billion; Asbury Park, New Jersey, including coastal area from Delaware to Connecticut $-\$ 52$ billion (class 4 hurricane); New York City $-\$ 45$ billion (class 4 hurricane).

A risk profile of the United States setting forth potential exposure to floods reflects equally dramatic exposure. It is important, however, to recognize that much of that exposure is insured by the National Flood Insurance Program, underwritten by the United States Government and not by the private insurance sector. Private insurers do insure flood risk in commercial policies, however. For example, the private sector sustained insured damages in the June-July $1993 \mathrm{Mid}$-west floods of approximately $\$ 745$ million, although total damage was estimated at $\$ 10.5$ billion.

\subsection{Today's losses from past disasters}

It is revealing to examine potential future losses, but it is perhaps more reflective to retrace our steps and examine past actual events and update them to current dollars and the current size of the insured market. Exhibits 4 and 5 list hurricane events in the United States from 1949 to 1992, reflecting the original loss paid updated to 1992 dollars and 1992 insured markets. This analysis shows that the loss from these huricannes would rise dramatically should there be a recurrence of the same natural events that have previously taken place. A similar analysis of storms in the United States, including floods from 1950 to 1993 , reflects tremendous increases in probable losses associated with previously encountered actual events. For example, in 1950 a storm that affected 14 states caused insured damages of $\$ 174$ million. Tracking the storm through those same states using today's insured values, the losses in 1992 dollars would be $\$ 6.6$ billion.

\subsection{Insurance industry reactions}

The U.S. insurance industry has learned four major lessons from recent natural catastrophes:

- Proper building codes and their enforcement could have reduced insured losses in Hurricane Andrew by 30 percent.

- Losses rise dramatically in natural catastrophes affecting thousands of people and property as compared with similar claims in isolated events.

- The insurance and reinsurance industries' limited capacity stands out in contrast to major natural disasters of $\$ 50$ billion to $\$ 80$ billion. 
Most Costly Insured Hurricanes in the US.

\begin{tabular}{|c|c|c|c|}
\hline Date & Event & $\begin{array}{c}\text { Original \$ } \\
\text { Estimated Loss } \\
(\$ \text { Mil. })\end{array}$ & $\begin{array}{l}92 \text { Market } \\
92 \$ \text { Mil. }\end{array}$ \\
\hline 1992, Aug. 30 & Hurricane Andrew $\cdot$ FL, LA & 16.000 .0 & 16.000 .0 \\
\hline 1965 , Sept. $7-10$ & Hurricane Betsy $\cdot \mathrm{FL}, \mathrm{AL}, \mathrm{MS}, \mathrm{LA}$ & 715.0 & 7.717 .3 \\
\hline 1989, Sept. $17-22$ & Hurricane Hugo $\cdot$ VI, PR, GA, SC, NC, VA & 4.295 .0 & 4.755 .4 \\
\hline 1954, Oct. 15-16 & Hurricane Hazel · SC, NC, VA, WV, DC, MD, DE, NJ, NY, PA & 122.1 & 3.328 .9 \\
\hline 1954, Aug. 30-31 & Hurricane Carol · NY, CT, RI, MA, ME, NH, NJ & 129.7 & 2.934 .6 \\
\hline 1970, Aug. 3 & Hurricane Celia $\cdot$ TX & 310.0 & 1.962 .5 \\
\hline 1960, Sept. 9-11 & Hurricane Donna $\cdot$ FL, MA, NJ, NY, NC, RI, VA & 91.0 & 1.625 .1 \\
\hline 1992, Sept. & Hurricane Iniki $\cdot \mathrm{HI}$ & 1.600 .0 & 1.600 .0 \\
\hline 1961, Sept. 9-12 & Hurricane Carla $\cdot$ TX, LA & 100.0 & 1.547 .7 \\
\hline 1979, Sept. 12-14 & Hurricane Frederic $\cdot \mathrm{MS}, \mathrm{AL}, \mathrm{FL}, \mathrm{LA}, \mathrm{TN}, \mathrm{KY}, \mathrm{WV}, \mathrm{OH}, \mathrm{PA}, \mathrm{NY}$ & 752.5 & 1.480 .1 \\
\hline 1950, Oct. 17 & Hurricane Unnamed $\cdot \mathrm{FL}$ & 10.5 & 1.318 .5 \\
\hline 1983, Aug. 17-20 & Hurricane Alicia · TX & 675.5 & 1.131 .2 \\
\hline 1949, Aug. 26 & Hurricane Unnamed · GL, GA, SC, NC & 8.3 & 1.091 .8 \\
\hline 1964, Aug. 26 & Hurricane Cleo $\cdot \mathrm{FL}$ & 67.2 & 1.026 .4 \\
\hline 1969, Aug. 17-18 & Hurricane Camille · LA, MI, AL, FL, TX & 225.0 & 991.0 \\
\hline 1988, Sept. 10-17 & Hurricane Gilbert · Dom Republic, Haiti, Jamaica, Mexico, US & 790.0 & 948.0 \\
\hline 1985, Aug. 30/Sept. 3 & Hurricance Elena $\cdot \mathrm{FL}, \mathrm{AL}, \mathrm{MS}, \mathrm{LA}$ & 543.3 & 703.5 \\
\hline 1955, Aug. 11 & Hurricane Connie · NC, PA, MD, NJ, NY & 28.2 & 642.4 \\
\hline 1991, Aug. 18-20 & Hurricane Bob $\cdot \mathrm{NC}, \mathrm{NY}, \mathrm{RI}, \mathrm{CT}, \mathrm{MA}$ & 620.0 & 629.3 \\
\hline 1967, June 27 & Hurricane Audrey $\cdot \mathrm{TX}, \mathrm{LA}$ & 32.2 & 608.8 \\
\hline 1972, June 17-25 & $\begin{array}{l}\text { Hurricane Agnes } \cdot \mathrm{FL}, \mathrm{GA}, \mathrm{SC}, \mathrm{NC}, \mathrm{VA}, \mathrm{WV}, \mathrm{OH}, \mathrm{MI}, \mathrm{P}, \mathrm{MD} \text {, } \\
\mathrm{DE}, \mathrm{DC}, \mathrm{NJ}, \mathrm{NY}, \mathrm{CT}, \mathrm{RI}, \mathrm{MA}, \mathrm{ME}, \mathrm{VT}\end{array}$ & 97.9 & 540.0 \\
\hline 1985, Sept. 26-27 & $\begin{array}{l}\text { Hurricane Gloria · NC, VA, MD, DE, PA, NJ, NY, CT, RI, MX, } \\
\mathrm{NH}, \mathrm{VT} \text {, ME }\end{array}$ & 418.7 & 515.9 \\
\hline 1975, Sept, 16-26 & $\begin{array}{l}\text { Hurricane Eloise } \cdot \text { FL, AL, GA, TN, WV, VA, MD, DE, DC, } \\
\text { PA, NJ, NY, MA, CT, R.I., P.R. }\end{array}$ & 119.2 & 435.2 \\
\hline 1954, Sept. 19 & Hurricane Edna $\cdot \mathrm{CT}, \mathrm{RI}, \mathrm{MA}, \mathrm{NH}, \mathrm{ME}$ & 12.5 & 388.4 \\
\hline 1967, Sept. 19 & Hurricane Bouloh $\cdot \mathrm{TX}$ & 34.0 & 319.8 \\
\hline 1979, Aug. 30/Sept. 6 & $\begin{array}{l}\text { Hurricane David · FL, FA, SC, NC, VA, MD, DC, DE, PA, NJ, } \\
\text { NY, CT, MA, P.R., V.I. }\end{array}$ & 122.1 & 264.9 \\
\hline
\end{tabular}

SOURCE: Property Claims Services (PCS) Division; American Insurance Services Group Inc. / Lehman Brothers. 


\section{EXHIBIT \# 5}

Most Costly U.S. Storms, Tornadoes, Floods

\begin{tabular}{|c|c|c|c|}
\hline Date & Event & $\begin{array}{c}\text { Original } \$ \\
\text { Estimated Loss } \\
\quad(\$ \text { Mil. })\end{array}$ & $\begin{array}{l}92 \text { Marke } \\
92 \$ \text { Mil. }\end{array}$ \\
\hline 1950 , Nov. 24 & Wind, rain, storm $\cdot 14$ states & 173.9 & 6.580 .1 \\
\hline 1993, Mar. 11-14 & Freeze, snow, ice, hail, wind (Josh) · 20 states & 1.625 .0 & 1.625 .0 \\
\hline 1974, Apr. 2 & Tornado, wind, hail $\cdot 17$ states & 430.6 & 1.432 .4 \\
\hline 1983, Dec. 17 & Freeze, snow, wind · ALL BUT 9 STATES & 880.0 & 1.231 .9 \\
\hline 1950 , May 4 & Hail, tornado, wind · IL, KS, MN, MO, NE & 25.8 & 1.211 .0 \\
\hline 1962, Oct. 11-13 & Windstorm · N. Calif., OR, WA & 81.0 & 1.093 .5 \\
\hline 1993, Jun. 16/Jul. 16 & Midwest floods & 900.0 & 900.0 \\
\hline 1992, Apr. $28-29$ & Wind, hail, tornadoes $\cdot \mathrm{TX}, \mathrm{OK}$ & 760.0 & 760.0 \\
\hline 1990, July 11 & Wind, hail, tornadoes $\cdot \mathrm{CO}$ & 625.0 & 659.9 \\
\hline 1992, Dec. $10-13$ & Wind, flood, snow (Beth) 10 states & 650.0 & 650.0 \\
\hline 1992, Mar. $24-25$ & Wind, hail, tornadoes, flood $\cdot \mathrm{TX}, \mathrm{LA}, \mathrm{Fl}$ & 610.0 & 610.0 \\
\hline 1992, June $19-20$ & Wind, hail, tornadoes $\cdot \mathrm{KS}, \mathrm{OK}$ & 570.0 & 570.0 \\
\hline 1989, Dec 21-26 & Freeze, ice, snow $\cdot 21$ states & 500.0 & 549.2 \\
\hline 1965, Apr. 11 & Tornadoes, hail · OH, MI, IN, IL, WI & 70.0 & 498.3 \\
\hline 1985, Jan. 19 & Freeze, snow, wind $\cdot 29$ states & 400.0 & 492.8 \\
\hline 1979, Apr. 10 & Flood, hail · AL, AR, GA, IL, IN, KS, LA, MS, MO, OK, TN, TX & 239.9 & 489.3 \\
\hline 1992 , Nov. $21-23$ & Wind, hail, tornadoes, flood 11 states & 425.0 & 425.0 \\
\hline 1990, Dec. $18-25$ & Wind, hail, tornadoes, freeze $\cdot 20$ states & 400.0 & 422.4 \\
\hline 1989, May 3-6 & Wind, hail, tornadoes, flood · IA, IN, OH, WV, NC, NE & 380.0 & 421.5 \\
\hline 1984, June 13 & Flood, hail, tornado, wind $\cdot \mathrm{CO}$ & 276.7 & 406.8 \\
\hline 1982, Apr. 2 & Hail, ice, tornado $\cdot 24$ states & 243.5 & 406.1 \\
\hline 1966, June 8 & Tornadoes, wind $\cdot$ Northeast Kansas & 57.0 & 403.5 \\
\hline
\end{tabular}

SOURCE: Property Claims Services (PCS) Division; American Insurance Services Group Inc./ Lehman Brothers. 
- The federal government has an enormous contingent, unfunded liability for disaster assistance (the federal government has spent $\$ 35$ billion on disaster assistance in the last five years).

Recent natural catastrophes, particularly Hurricane Andrew in August 1992 and the Northridge Earthquake of January 1994, have energized our industry to address the potential effects of natural catastrophes and changing climate patterns. In January 1994 the industry created the Insurance Institute for Property Loss Reduction, committed to study coastal building codes and their enforcement and develop an evaluation grading system for those codes that, like fire codes and departments, will be used as part of the industry's rating system. The Institute will also develop a wind damage evaluation system for commercial structures and begin research on building materials, methods and techniques to assist the construction industry in supplying homes and business that are more highly resistant to wind and water damage from natural events.

Many companies in our industry are also re-evaluating their contract coverage, the expansion of which has been a contributing factor to the increased insured losses sustained in recent years. Thus, companies are evaluating the size of deductibles in insurance contracts, the potential value to insureds and insurers in creating deductibles solely associated with hurricanes, guaranteed replacement cost coverages and coverage for additional living expense. The examination of these coverages is designed to help insureds with the probable increase in the cost of homeowners and commercial coverages necessitated by the extraordinary increases in loss experience. Based upon management's analysis and, in some cases, regulatory scrutiny, some companies in our industry are evaluating their commitment to insure in high-risk coastal areas and earthquake areas at current market conditions. Naturally, this has created some tension between insurers, insurance agents and regulatory officials as they strive to maintain insurance markets without threatening the solvency of the insurers themselves.

Some segments of the industry are also promoting state catastrophe funds which involve state government in a risk bearing role associated with natural disasters. These funds have been advocated in Florida (unsuccessfully), California (pending) and Hawaii (successfully) as a mechanism to shift some of the financing of insured losses onto the states.

Our industry has also supported the Natural Disaster Protection Act, a proposal now pending before the Congress. The Natural Disaster Protection Act is designed to reduce the loss of life and property, as well as the economic consequences of future natural disasters. It accomplishes this goal through a program which does the following:

- Promotes loss reduction through better enforcement of building codes and improved emergency planning;

- Creates a privately-financed mitigation fund to provide states and local governments with additional resources to prepare for future catastrophe;

- Broadens homeowner's insurance to include protection against disasters not presently covered in standard policies, particularly earthquakes; and

- Assures the future availability of homeowner's coverage in all regions of the country, even in the aftermath of a major disaster.

The proposal emphasizes a partnership between the state and federal government and the private insurance sector and will ultimately reduce the reliance on federal disaster relief. 
The following is a summary of the key legislative provisions:

\subsection{Disaster loss reduction}

This program provides incentives to state and local governments to enhance their disaster planning and mitigation efforts in coordination with the Federal Emergency Management Agency (FEMA). The incentives include new funding sources for mitigation and improved and more affordable insurance protection for homeowners.

To qualify for the incentives, states would be required to:

- Adopt one of several model building and safety codes designed to make new constructions less vulnerable to hurricanes, floods, earthquakes and other natural perils.

- Submit a comprehensive disaster plan to FEMA that includes detailed steps for identifying at-risk structures and methods to improve building code enforcement, emergency response and overall disaster preparedness.

- Comply with the building codes and implement new mitigation plans within five years.

States meeting each of these criteria would be eligible for grants from a Federal Disaster Mitigation Fund, which would be financed by setting aside 5-10 percent of the funds collected in the programs described below. States not in compliance would be ineligible for these funds and could be denied access to certain types of federal disaster relief.

In addition to the state initiatives, FEMA would expand its efforts to encourage improved disaster training, research, technology transfer and education.

\subsection{Expanded insurance protection against natural disasters}

In addition to the mitigation program, the legislation also creates incentives for insurance companies to provide a more comprehensive homeowner's policy that includes federal government coverage for earthquake and several other perils not currently included in basic coverage. In addition, the National Flood Insurance Program could be integrated into the program following a one year study with the concurrence of Congress and the President.

Rates for this coverage would be risk-based so that homeowners in areas prone to such hazards would not be subsidized by residents for low-risk areas. In addition, homeowners would still have a choice of deductibles, type of coverage and additional endorsements.

FEMA would set the premiums and deductibles for these expanded lines of coverage. Insurance companies would collect the premiums and remit them to a Federal Trust Fund which would be used to pay claims.

\subsection{Reinsurance program}

The Natural Disaster Protection Act addresses the homeowners' insurance availability problems which have occurred in the wake of recent disasters and helps to avoid even greather availability problems in the aftermath of a future catastrophe. It also reduces the potential for insurance company insolvencies from exceptionally large disasters.

This would be accomplished through the creation of a new federal disaster Reinsurance Fund that would be financed entirely by the insurance industry. The Reinsurance Fund would provide a source of federal reinsurance which insurers could purchase to better manage the risk from highly infrequent, but extremely costly disasters, such as hurricanes.

Premiums for the reinsurance program would be set by FEMA, with companies making payments into a National Reinsurance Fund. Over time, the fund will accumulate 
reserves to be used when a large disaster strikes. If such an event occurs before a sufficient reserve has accumulated, the Treasury would be authorized to borrow additional funds to cover the shortfall and then charge insurers, with interest, to rebuild the fund.

Participating insurers would only be eligible to make claims against the fund if a natural disaster, or series of disasters occurring in a 12 month period, exceeded 15 percent of the industry's surplus, ${ }^{2}$ currently estimated at $\$ 27$ billion. Individual companies could also make claims if they experienced a 20 percent reduction in their surplus as a result of a single disaster.

States also would be eligible to participate in the reinsurance program if they create insurance pools or other state-sponsored programs to provide insurance for homeowners who are unable to secure coverage on their own.

The Natural Disaster legislation is scheduled for consideration by Congress this summer, following an analysis and recommendations from the Clinton Administration. The proposal is broadly supported within the U.S. industry.

This federal proposal and the industry's support of state catastrophe funds reflects a new philosophy on the part of U.S. insurers that government (i) should do more to mitigate loss of life and property associated with natural catastrophes, (ii) assume an underwriting, risk bearing role, and (iii) not socialize this societal risk on the sole basis of private capital.

\section{Insurer liability under superfund}

Since its inception in 1980, the United States' hazardous waste clean-up program (commonly known as Superfund) has proven controversial. Reauthorized and expanded in 1986, the program grew in scope, expense and complexity. And in 1990, the U.S. Congress deferred decisions until 1994 and gave the program another four year reprieve without any major changes. Recent developments have given some in the insurance industry reason to believe that there may be some light at the end of this painfully long and frightfully dark tunnel.

The law was originally designed to force those that caused hazardous waste to pay for its clean-up. It utilizes legal doctrines of strict, joint and several and, astonishingly, retroactive liability on those who contributed to harzardous sites. As the government began determining which sites had to be cleaned, polluters began turning to their insurers and demanding coverage under comprehensive general liability policies. Insurers argued - and continue to argue - that their contracts did not include long term environmental risks, but various U.S. state and federal courts have interpreted identical language inconsistently. The U.S. Supreme Court, upholding its traditional reluctance to decide contract disputes, has steered clear of the issue, so a consistent reading of the law appears unlikely in the near-term.

The cost of resolving disputes between responsible parties and insurers has been a tremendous drain of resources away from clean-up efforts. The Rand Corporation estimates that the transaction costs in legal and consulting fees resulting from this uncertainty account for almost one-third of all private-sector costs associated with Superfund. ${ }^{3}$ Nearly 88

\footnotetext{
2 The current industry-wide surplus is estimated at $\$ 183$ billion.

${ }^{3}$ Dixon, Lloyd S., Deborah S. Drezner, and James K. Hamitt, Private-Sector Cleanup Expenditures and Transaction Costs at 18 Superfund Sites, RAND, MR-204-EPA, 1993.
} 
percent of funds paid by insurers have gone to defense costs for policyholders and litigation over coverage questions. The remainder, 12 percent, has gone to clean-up.

Over the next 30 years, these costs together with future liability clean-up costs are estimated by A.M. Best to total $\$ 250$ billion for insurers, U.S. and foreign, that provided environmental coverage during the 1960's, 1970's and 1980's. Best's "worst case" estimates are $\$ 623$ billion. To put this in perspective, total U.S. property casualty surplus is $\$ 183$ billion. Best's states that the surplus of the 47 company groups that wrote most commercial insurance coverage in this period is only $\$ 65$ billion. Lastly, an analysis of insurer financial statements by Best's suggests only $\$ 12$ billion in reserves currently set aside to pay these claims.

For their part, insurers have proposed two major alternatives to the current scheme. The first would convert the plan from a liability-based scheme to a government operated Superfund program, combining a $\$ 300$ million annual tax on commercial insurance premiums with increased surtaxes on other industries to eliminate all liabilities prior to 1980 .

The second is a compromise aimed at reducing the transaction costs, particularly insurance coverage disputes. The proposal would require insurers to pay an annual tax to a national trust fund in exchange for eliminating insurance coverage litigation over sites which were on the existing National Priorities List (the EPA's list of the nation's worst hazardous waste sites).

\subsection{How the program would work}

- Insurers would make payments into a new Environmental Insurance Resolution Fund (EIRF) to handle claims for insurance coverage of clean-ups of pre-1986 wastes. Depending on the Fund's needs, insurers would provide between $\$ 2.5$ billion and $\$ 3.1$ billion over the first five years - and up to $\$ 8.1$ billion over 10 years.

- Before they could initiate or continue legal action against their insurers, parties responsible for clean-up of hazardous sites would be required to file a claim with the Fund for reimbursement of clean-up costs at all their Superfund sites on the national priority list. All litigation would be stayed during this claims process.

- Claims would be contingent on certain proof of insurance by the potentially responsible party.

- The Fund would offer a settlement for a percentage of the claims, based on the likelihood of the responsible party recovering from insurers in relevant state courts. Those percentages would be based on the history of court decisions in each state as of January 1, 1994, with 60 percent in states where decisions generally favor business, 20 percent where decisions favor insurers, and 40 percent in states where the law remains uncertain.

- Responsible parties not accepting the Fund's offer could choose to sue their insurers, but the insurers would be protected up to the settlement amount offered by the Fund. Also, a disincentive would be included to encourage businesses' participation in the Fund system.

- The settlement would include all past, present and future claims over those sites.

- The Fund would not begin payouts until 85 percent of all existing responsible parties decide to accept the Fund's offers. If the Fund went out of business, insurers would be refunded their contributions to the Fund, minus administrative expenses. 
The scheme would not eliminate all insurer Superfund costs. Non-Superfund sites, which comprise a substantial portion of hazardous waste sites, would not be subject to the allocation process, nor would sites that have not yet been subject to the panel's deliberations. In addition, no agreement on how the industry would bear the tax has been reached. Some insurers have argued that the proposal's presumed settlement percentages are too generous. Others point out that the basic problem of eliminating the inequity of retroactive liability has not been addressed.

Despite these flaws, the concept has formed the basis of the Clinton Administration's recommendations to Congress. Naturally, Congress may alter the proposal substantially as it reviews, debates and adopts some form of reauthorization of Superfund in 1994.

Nevertheless, the industry is seeking to reverse a law which essentially goes beyond the limits of insurability by attempting to create a past exposure for clean-up and socializing it through the private sector.

\section{Conclusion}

Two of the U.S. insurance industries most troublesome exposures, natural catastrophes and environmental liability under Superfund, are the current subject of aggressive efforts to find solutions. In both cases, administrative schemes involving government as a partner with insurers are being pursued.

The success of these efforts will be clear before the end of 1994. If these efforts prove unsuccessful, eventually the economics of each will force public solutions. These economics, insurers, consumer, and government, if honestly understood, already demand new government initiatives to address broad public problems. Hopefully, the government will act now and not allow the situation to deteriorate further. 